\title{
CONHECIMENTO ESPÍRITA E SUAS POSSIBILIDADES: A APROPRIAÇÃO DESTE POR ALGUMAS ÁREAS DE CONHECIMENTO
}

\author{
Orientando: Libni Milhomem Sousa \\ Graduado em Biblioteconomia \\ libnimilhomem@hotmail.com \\ Orientador: Lucas Veras de Andrade \\ Professor Especialista \\ Secretaria Municipal de Educação de Teresina (PI) \\ lukkandrade18@hotmail.com
}

\begin{abstract}
Resumo
Este trabalho tem como proposta demonstrar a apropriação do conhecimento espírita por algumas áreas do conhecimento. Para este propósito, nos utilizamos como recorte quatro categorias de análise, demarcadas através da tabela de classificação de conhecimento, do Conselho Nacional de Desenvolvimento Científico e Tecnológico (CNPq), sendo estas: Linguística, Letras e Artes; Ciências Humanas; Ciências Sociais Aplicadas e Ciências da Saúde, desmembrando-se nas subáreas: Literatura, Cinema, Biblioteconomia, Sociologia, Psicologia e Medicina. Considerando que a literatura espírita transita sobre as mais diversas áreas, verificou-se a necessidade de analisar como esse tema é abordado nas áreas de conhecimento escolhidas. A partir do desenvolvimento da doutrina espírita, várias obras foram escritas e o tema passa a ser comentado nas mais diversas áreas de conhecimento, reforçando seu caráter intelectual. Para tanto, foi realizada pesquisa de caráter bibliográfico e revisão de literatura, através da leitura de livros, artigos, pesquisa em sites, dissertações e outras fontes ligadas à proposta do estudo. Ao finalizarmos, percebemos a influência do conhecimento espírita para suporte a outras áreas no que tange as reflexões sobre a espiritualidade voltadas para um olhar científico, subsidiando-as de respaldo para validação dos trabalhos. Nessa perspectiva concluímos que o conhecimento espírita é transversal, podendo ser utilizado para amparar cientificamente uma vasta variedade de estudos, auxiliando na composição de trabalhos que demandem a compreensão a partir do campo espiritual e sobre o olhar espírita.
\end{abstract}

Palavras-Chave: Conhecimento Espírita. Alan Kardec. Cinema. Literatura. Biblioteconomia. Sociologia. Psicologia. Medicina. 